\title{
PROSES BERPIKIR KRITIS BERDASARKAN GAYA BELAJAR DALAM MEMECAHKAN MASALAH SOAL CERITA MATEMATIKA
}

\author{
Sufyan $^{1}$, Rukli2 $^{2}$, Agustan $^{3}$ \\ 1,2,3 Universitas Muhammadiyah Makassar, Indonesia \\ ${ }^{1}$ sufyansufyan23@gmail.com, ${ }^{2}$ rukli23@yahoo.com,3agustan@unismuh.ac.id
}

\begin{abstract}
ABSTRAK
Penelitian ini bertujuan untuk mendapatkan gambaran proses berpikir kritis peserta didik dalam pemecahan masalah matematika ditinjau dari gaya belajar visual, auditori dan kinestetik. Identifikasi proses berpikir kritis didasarkan atas langkah-langkah berpikir kritis IDEALS yakni Identify, Define, Enumerate, Analyze, List and Self Correct. Subjek penelitian terdiri dari 3 peserta didik yang masing-masing memiliki gaya belajar visual, auditori dan kinestetik yang memiliki nilai tertinggi. Penelitian ini menggunakan metode deskriptif kualitatif dengan teknik pengumpulan data melalui observasi, wawancara, dokumentasi dan hasil tes peserta didik di Sekolah. Oleh karena itu, triangulasi yang digunakan adalah triangulasi teknik. Hasil penelitian proses berpikir kritis siswa visual, auditori, dan kinestetik pada langkah identify, enumerate, analyze, list dan self-correct memiliki kesamaan dalam memecahkan masalah berbentuk soal cerita. Perbedaan proses berpikir kritis tersebut paling menonjol terlihat pada langkah define. Perbedaannya terletak pada cara dan saat menjelaskan bentuk akuarium berdasarkan fakta dan alasan logis yang diberikan, perbedaan yang lain terletak pada ketelitian siswa dalam memeriksa kembali jawaban yang diperoleh karena subjek auditori sempat menambahkan catatan dalam jawabannya. Siswa kinestetik dapat dikatakan memiliki proses berpikir kritis lebih baik dibandingkan siswa visual pada langkah define.
\end{abstract}

Kata Kunci: proses berpikir kritis, gaya belajar, memecahkan masalah, soal cerita matematika

\section{CRITICAL THINKING PROCESS BASED ON LEARNING STYLES IN SOLVING THE PROBLEMS IN MATHEMATIC STORY QUESTIONS}

\begin{abstract}
This study aimed to obtain an overview of students' critical thinking processes in solving mathematical problems in terms of visual, auditory, and kinesthetic learning styles. The identification of critical thinking processes was based on IDEALS critical thinking steps, namely Identify, Define, Enumerate, Analyze, List, and Self Correct. The research subject consisted of 3 students, each of whom had the highest score of visual, auditory, and kinesthetic learning styles. This study utilized a qualitative descriptive method with data collection techniques through observation, interviews, documentation, and test results of students at school. Therefore, the triangulation used was technical triangulation. The results of the research on the visual, auditory, and kinesthetic students' critical thinking processes in the step of identifying, enumerating, analyzing, listing, and self-correcting had similarities in solving story problems. The difference in the critical thinking process was most prominently seen in the first step, define. The difference lied in the way and when explaining the shape of the aquarium based on the facts and logical reasons given; another difference lied in the students accuracy in re-examining the answers obtained because the subject of the auditory had added notes in his answer. The kinesthetic student was said to have a better critical thinking process than the visual student in the first step, define. Meanwhile, the visual student was said to have a better critical thinking process than the auditory student because the auditory student had doubts about what was asked in the question.
\end{abstract}

Keywords: critical thinking process, learning styles, problem solving, math story problems

\begin{tabular}{|c|c|c|}
\hline Submitted & Accepted & Published \\
\hline 10 Agustus 2021 & 29 Oktober 2021 & 24 November 2021 \\
\hline
\end{tabular}

\begin{tabular}{|l|l|r|r|}
\hline Citation & $:$ & $\begin{array}{r}\text { Sufyan, S., Rukli, R., \& Agustan, A. (2021). Proses Berpikir Kritis Berdasarkan Gaya Belajar Dalam Memecahkan } \\
\text { Masalah Soal Cerita Matematika. Jurnal PAJAR (Pendidikan dan Pengajaran), 5(6), 1674-1687. DOI : } \\
\text { http://dx.doi.org/10.33578/pjr.v5i6.8502. }\end{array}$ \\
\hline
\end{tabular}

\section{PENDAHULUAN}

Belajar melibatkan proses berpikir dalam diri setiap manusia, untuk mencapai berbagai macam kompetensi, keterampilan dan sikap. Berpikir selalu dilakukan oleh setiap orang atau individu dan berlangsung terus menerus. Melalui berpikir, manusia dapat belajar meningkatkan kualitas hidupnya di masyarakat (Suharna, 2012).

Suharna (2012) mengemukakan bahwa berpikir yang dibangun sejak awal dalam upaya menyelesaikan suatu masalah hendaknya berlangsung secara maksimal, hal ini 
dimaksudkan agar peserta didik menjalani proses berpikir sehingga terlatih dan memperoleh kesempatan untuk memberdayakan dan memfungsikan kemampuan yang ada pada setiap individu, sehingga berakibat peserta didik memahami serta menguasai apa yang dipelajari.

Ramalisa (2013) menyatakan bahwa keterampilan berpikir kritis ini berkaitan dengan kemampuan mengidentifikasi, menganalisis, dan memecahkan masalah secara kreatif serta berpikir logis sehingga menghasilkan pertimbangan dan keputusan yang tepat. Seseorang berpikir kritis jika menyatakan suatu hal dan mencari informasi dengan tepat kemudian informasi tersebutlah yang digunakan untuk memecahkan masalah yang dihadapi dengan tepat berdasarkan analisis dan pengetahuan yang dimilikinya.

Proses berpikir yang dilakukan oleh peserta didik bertujuan untuk memecahkan masalah, pentingnya pemecahan masalah ditegaskan dalam National Council of Teacher Mathematics (2000) menetapkan bahwa terdapat 5 standar proses yang perlu dimiliki peserta didik dalam pembelajaran matematika, yaitu:
Pemecahan Masalah, Penalaran dan Pembuktian, Komunikasi, Koneksi dan Representasi. Standar proses NTCM termasuk pada berpikir matematika tingkat tinggi (high order mathematical thinking) yang harus dikembangkan dalam proses pembelajaran matematika. Penegasan tersebut berkaitan erat dengan proses berpikir kritis dalam pemecahan masalah. Jadi, seseorang mampu mempertanggungjawabkan setiap asumsiasumsinya lewat proses berpikir kritis.

Amir (2015) menyatakan bahwa berpikir kritis juga lebih kompleks dari berpikir biasa pada umumnya yang hanya memahami konsep atau masalah saja tanpa bisa mengidentifikasi dan mengeksplorasi masalah untuk mencari solusi lebih lanjut karena berpikir kritis membutuhkan kemampuan mental dan kemampuan intelektual yang lebih tinggi.

Al- Quran pun memberitakan terkait hal ini, bahwa berpikir kritis itu diperlukan dalam kehidupan sehari-hari dalam hal ini tentunya tidak lepas dari matematika. Seperti yang dikutip dalam Al quran:

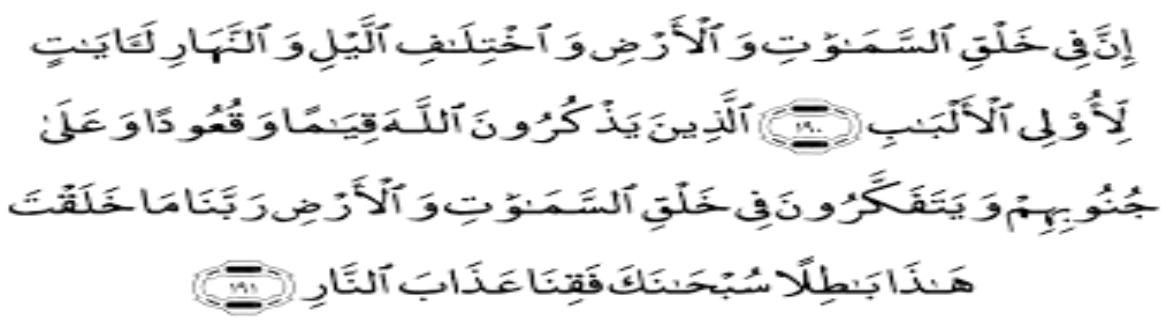

Terjemahannya "Sesungguhnya dalam penciptaan langit dan bumi, dan silih bergantinya malam dan siang terdapat tanda-tanda bagi orang-orang yang berakal, (yaitu) orang-orang yang mengingat Allah sambil berdiri atau duduk atau dalam keadan berbaring dan mereka memikirkan tentang penciptaan langit dan bumi (seraya berkata): "Ya Tuhan kami, tiadalah Engkau menciptakan ini dengan sia-sia, Maha Suci Engkau, maka peliharalah kami dari siksa neraka." (Surah Al- Imran ayat 190-191)

Salah satu tujuan diajarkan mata pelajaran matematika adalah membentuk peserta didik yang mampu berpikir kreatif, kritis, dan mandiri yang tertuang dalam Peraturan Menteri Pendidikan Nasional RI no. 20 thn 2016.
Penelitian ini nantinya akan terfokus kepada peserta didik dengan gaya belajar visual, auditori dan kinestetik. Seperti yang diungkapkan oleh Susilo (2006) "Gaya belajar (learning styles) merupakan suatu proses gerak laku, penghayatan, serta kecenderungan seorang pelajar mempelajari atau memperoleh suatu ilmu dengan caranya yang tersendiri". Dengan demikian, diperlukan suatu penelitian untuk mengidentifikasi proses berpikir kritis peserta didik sekolah dasar dalam memecahkan soal cerita ditinjau dari gaya belajar.

Keterampilan berpikir kritis ini berkaitan dengan kemampuan mengidentifikasi, menganalisis, dan memecahkan masalah secara kreatif serta berpikir logis sehingga menghasilkan pertimbangan dan keputusan yang tepat. Seseorang berpikir kritis jika menyatakan suatu 
hal dan mencari informasi dengan tepat kemudian informasi tersebutlah yang digunakan untuk memecahkan masalah yang dihadapi dengan tepat berdasarkan analisis dan pengetahuan yang dimilikinya.

Menurut Abrori (dalam Ramalisa, 2013) tidak semua orang yang mempunyai banyak pengetahuan atau seseorang yang pandai mampu malakukan proses berpikir kritis. Orang yang sangat pandai kadang-kadang berpikir tidak rasional atau malah berpikir tidak logis. Sedangkan berpikir kritis merupakan suatu keterampilan yang menggunakan pengetahuan dan inteelgensi untuk mendapatkan obyektivitas dan pandangan yang dapat diterima secara akal.

Jadi, dari berbagai penjelasan diatas banyak tantangan untuk mengetahui secara mendalam kepribadian peserta didik karena setiap orang memiliki progres yang berbeda-beda. Facione (dalam Peter, 2012) menjelaskan untuk mengetahui aktivitas mental siswa dalam berpikir kritis memecahkan suatu masalah dapat menggunakan langkah-langkah Identify, Define, Enumerate, Analyze, List, Self-Correct. Langkahlangkah ini dapat disingkat dengan IDEALS, berikut penjelasan masing-masing langkah tersebut.

a) Identify (I) Menentukan ide pokok permasalahan yang dihadapi

b) Define (D) Menentukan fakta-fakta yang membatasi masalah, fakta-fakta permasalahan yang dimaksud meliputi apa saja yang diketahui, ditanya pada soal, serta informasi apa yang tidak digunakan atau tidak diperlukan.

c) Enumerate (E) Menentukan atau mendaftar pilihan-pilihan jawaban yang mungkin dari masalah secara masuk akal.

d) Analyze (A) Menganalisis pilihan jawaban apa yang terbaik untuk diambil sebagai suatu pilihan

e) List (L) Menyebutkan alasan yang tepat mengapa pilihan jawaban yang dipilih terbaik

Self-Correct (S) Mengecek kembali secara menyeluruh, apakah ada tindakan-tindakan untuk menyelesaikan soal yang terlewati.

\section{KAJIAN TEORETIS}

1. Memecahkan Persoalan
Pembelajaran berhitung merupakan salah satu pembelajaran yang memuat masalah kehidupan sehari-hari (Rahardjo \& Waluyati, 2011)

Menurut Dhoruri (dalam Rohati, 2014) pemecahan masalah merupakan hal yang sangat penting dalam pembelajaran matematika, sehingga hampir disemua Standar Kompetensi dan Kompetensi Dasar dijumpai penegasan diperlukannya kemampuan pemecahan masalah.

Visitasari (2013) mengemukakan bahwa memecahkan masalah merupakan suatu serangkain proses tertentu yang dilakukan peserta didik dalam menghadapi situasi yang direpresentasikan ke dalam pertanyaan dan pertanyaan disadari oleh peserta didik, serta menantang untuk diselesaikan meskipun tidak dapat segera ditentukan strategi untuk menjawab pertanyaan yang dihadapi.

Visitasari (2013) mengemukakan bahwa beberapa pendapat para ahli yang mendukung pentingnya pemecahan masalah bagi peserta didik antara lain menyatakan bahwa:

a. Kemampuan pemecahan masalah sebagai salah satu hasil dari pembelajaran matematika yang harus dimiliki oleh peserta didik, sehingga diharapkan peserta didik menjadi individu yang mampu menyelesaikan masalah yang dihadapinya sendiri (Depdiknas, 2006),

b. Kemampuan pemecahan masalah sebagai salah satu komponen proses yang melibatkan peserta didik dalam memahamkan matematika (NCTM, 2000),

c. Keterampilan dan pengetahuan pemecahan masalah nantinya akan digunakan dan diaplikasikan di dalam kehidupan nyata dalam menghadapi masalah apapun (Shadiq, 2004).

Jadi berdasarkan kajian diatas, yang dimaksud dengan pemecahan masalah adalah merupakan proses atau usaha seseorang dalam merespon masalah ataupun kendala yang jawabannya belum nampak jelas dan belum tentu menjadi masalah bagi orang lain.

\section{Soal Cerita Matematika}

Asmad (2017) mengatakan bahwa matematika merupakan ilmu universal yang mendasar perkembangan teknologi modern, dengan belajar matematika kapasitas olah pikir, 
daya intelektual dapat dikembangkan sesuai dengan potensi peserta didik didik secara optimal.

Nitya (2013) mengemukakan bahwa matematika merupakan salah satu mata pelajaran yang diajarkan pada setiap jenjang pendidikan, mulai dari pendidikan dasar sampai perguruan tinggi. Salah satu dasar pertimbangannya karena Matematika adalah suatu alat untuk mengembangkan cara berpikir yang mendasari perkembangan teknologi modern. Matematika sangat diperlukan baik dalam kehidupan seharihari maupun dalam menghadapi kemajuan ilmu pengetahuan dan teknologi.

Secara struktural, soal cerita dibangun oleh tiga unsur atau bagian, yaitu situasi awal, peristiwa (event), dan pertanyaan (Gerofsky, 1996). Sumarwati (2008) mengemukakan bahwa unsur situasi awal biasanya berupa kalimat pertama atau kedua. Unsur peristiwa, yaitu kejadian yang mengubah situasi, biasanya ditempatkan sesudah unsur situasi. Adapun unsur pertanyaan adalah kalimat yang menanyakan pengaruh atau akibat berubahnya situasi karena adanya unsur peristiwa. Oleh karenanya, pengembangan soal cerita harus memerhatikan keberadaan ketiga unsur di atas.

Jadi, dapat disimpulkan bahwa kemampuan menyelesaikan soal cerita adalah merupakan proses atau usaha seseorang dalam merespon masalah ataupun kendala yang jawabannya belum nampak jelas dan belum tentu menjadi masalah bagi orang lain, mengasah olah pikir dan daya intelektual dalam bentuk media bahasa, yang bercerita tentang kehidupan seharihari yang membutuhkan matematika

\section{Gaya Belajar}

Hamzah (2008) menyatakan bahwa "Ada beberapa tipe gaya belajar yang bisa kita cermati dan mungkin kita ikuti apabila memang kita merasa cocok dengan gaya itu, diantaranya: gaya belajar visual, gaya belajar auditorial dan gaya belajar kinestetik".

Seperti yang diungkapkan oleh Susilo (2006) "Gaya belajar (learning styles) merupakan suatu proses gerak laku, penghayatan, serta kecenderungan seorang pelajar mempelajari atau memperoleh suatu ilmu dengan caranya yang tersendiri"

Melvin (2014) menyatakan bahwa setiap 30 peserta didik, 22 diantaranya rata-rata dapat belajar dengan efektif selama gurunya menghadirkan kegiatan belajar yang berkombinasi antara visual, auditori, dan kinestetik. Namun sisanya sedemikian menyukai salah satu bentuk pengajaran dibanding dua lainnya, sehingga peserta didik tersebut harus berupaya keras untuk memahami pelajaran bila tidak ada kecermatan dalam menyajikan pelajaran sesuai dengan cara yang mereka sukai. Sari (2014) mengemukakan jika seorang peserta didik menangkap informasi/materi sesuai dengan gaya belajarnya, maka tidak akan ada pelajaran yang sulit.

Menurut teori yang dikemukakan oleh Bandler dan Grinder (dalam DePorter, 2010) gaya belajar ada 3 yakni belajar visual, auditori, dan kinestetik, dan setiap individu cenderung pada salah satu dari ketiga gaya belajar tersebut.

Putri (2013) menyatakan bahwa gaya belajar merupakan salah satu dari faktor-faktor yang mempengaruhi hasil belajar peserta didik yang tidak kalah pentingnya. Cara atau gaya belajar yang berbedabeda mempunyai pengaruh pada hasil belajar peserta didik. Gaya belajar merupakan suatu strategi yang dilakukan oleh peserta didik dalam belajarnya untuk mencapai tujuan yang diharapkan yaitu hasil belajar yang baik.

Tujuan pembelajaran yang diinginkan tentu yang optimal, untuk itu ada beberapa hal yang perlu diperhatikan oleh pendidik, salah satunya yang penting adalah pendidik perlu mengetahui tipe gaya atau gaya belajar peserta didiknya, agar pendidik dapat menyesuaikan metode apa yang akan diterapkan pada saat mengajar sehingga tujuan pengajaran yang telah dirumuskan oleh pendidik dapat terwujud/tercapai.

Gaya belajar seseorang adalah kombinasi dari bagaimana ia menyerap dan kemudian mengatur serta mengolah informasi". Menurut Nasution (2003), "gaya belajar atau Learning style adalah ia cara bereaksi dan menggunakan perangsang-perangsang yang diterimanya dalam proses belajar". Lebih lanjut dikatakan gaya belajar adalah cara yang konsisten yang dilakukan oleh peserta didik dalam menangkap stimulus atau informasi, cara mengingat, berfikir dan memecahkan persoalan.

Amina (2016) mengemukakan bahwa setiap individu memiliki karakter tersendiri dalam 
mengembangkan cara belajarnya dan daya pikir dalam menyelesaikan sebuah permasalahan yang dihadapi. Menurut Hasruddin dan Rezeqi (2012), mengajarkan ilmu kepada peserta didik dikatakan baik jika memenuhi kriteria, yaitu sesuai dengan hakikat ilmu itu dan sesuai dengan pengetahuan tentang bagaimana peserta didik belajar. Karakteristik yang dimiliki setiap peserta didik tersebut juga ditegaskan dalam Permendiknas No. 41 Tahun 2007 (Kurikulum 2006) dan Permendikbud No. 22 Tahun 2016 (Kurikulum 2013) tentang Standar Proses Pendidikan Dasar dan Menengah, yang mengisyaratkan bahwa dalam proses pembelajaran, seorang guru seyogyanya dapat memperhatikan karakteristik peserta didiknya.

Gaya belajar adalah tipe belajar seseorang dalam memecahkan persoalan, menangkap stimulus atau menyerap informasi baru / pengetahuan baru, karena setiap orang memiliki cara tersendiri dalam merespon informasi, tentunya cara belajar yang berbeda beda memiliki pengaruh pada hasil belajar. Gaya belajar ada 3 Visual Auditori dan Kinestetik. Visual adalah gaya belajar yang menangkap informasi lewat penglihatan, auditori adalah gaya belajar yang mengandalkan pada pendengaran untuk dapat memahami dan mengingat informasi, dan Kinestetik adalah aktivitas belajar dengan cara gerak, bekerja dan menyentuh agar mendapatkan informasi.

\section{Proses Berpikir Kritis Berdasarkan Gaya Belajar Dalam Memecahkan Masalah Soal Cerita Matematika}

Asmad (2017) mengemukakan bahwa Sekolah Dasar merupakan satuan pendidikan dasar yang bertujuan meletakkan dasar kecerdasan yaitu membaca, menulis, dan berhitung.

Gaya belajar adalah tipe belajar seseorang dalam memecahkan persoalan, menangkap stimulus atau menyerap informasi baru / pengetahuan baru, karena setiap orang memiliki cara tersendiri dalam merespon informasi, tentunya cara belajar yang berbeda beda memiliki pengaruh pada hasil belajar. Gaya belajar ada 3 Visual Auditori dan Kinestetik. Visual adalah gaya belajar yang menangkap informasi lewat penglihatan, auditori adalah gaya belajar yang mengandalkan pada pendengaran untuk dapat memahami dan mengingat informasi, dan Kinestetik adalah aktivitas belajar dengan cara gerak, bekerja dan menyentuh agar mendapatkan informasi.

Secara sederhana dapat disimpulkan bahwa proses berpikir kritis merupakan langkahlangkah konkrit yang dilakukan seseorang dalam hal ini peserta didik, dari berbagai cara ataupun gaya masing-masing yang direspon peserta didik dalam menyelesaikan berbagai persoalan / masalah dari soal cerita matematika.

Kemampuan menyelesaikan soal cerita adalah merupakan proses atau usaha seseorang dalam merespon masalah ataupun kendala yang jawabannya belum nampak jelas dan belum tentu menjadi masalah bagi orang lain, mengasah olah pikir dan daya intelektual dalam bentuk media bahasa, yang bercerita tentang kehidupan seharihari yang membutuhkan matematika

\section{METODE PENELITIAN}

Jenis penelitian ini adalah penelitian deskriptif dengan pendekatan kualitatif untuk mengidentifikasi proses berpikir kritis siswa SD dalam memecahkan masalah berbentuk soal cerita ditinjau dari perbedaan gaya belajar V-A-K (visual, auditori, kinestetik) siswa. Proses berpikir kritis tersebut dalam penelitian ini diidentifikasi berdasarkan langkah-langkah berpikir kritis IDEALS.

Tabel 1. Langkah-Langkah Dan Indikator Berpikir Kritis

\begin{tabular}{lll}
\hline No & $\begin{array}{c}\text { Langkah- } \\
\text { langkah Berpikir } \\
\text { Kritis }\end{array}$ & \multicolumn{1}{c}{ Indikator } \\
\hline 1 & (I) Identify & Menyebutkan pokok permasalahan \\
2 & (D) Define & Menyebutkan fakta-fakta yang membatasi masalah meliputi: \\
& & Menyebutkan informasi-informasi yang dibutuhkan meliputi apa yang \\
& & diketahui dan ditanyakan dalam soal.
\end{tabular}


Jurnal PAJAR (Pendidikan dan Pengajaran)

Volume 5 Nomor 6 November | ISSN Cetak : 2580 - 8435 | ISSN Online : 2614 - 1337

DOI : http://dx.doi.org/10.33578/pjr.v5i6.8502

$\begin{array}{ll}3 & \text { (E) Enumerate } \\ 4 & \text { (A) Analyze } \\ 5 & \text { (L) List } \\ 6 & \text { (S) Self-Correct }\end{array}$

- Menyebutkan informasi-informasi yang tidak digunakan

Menyebutkan pilihan-pilihan cara dan jawaban yang masuk akal Menganalisis pilihan untuk memilih cara dan jawaban terbaik

Menyebutkan alasan yang tepat atas cara dan jawaban terbaik yang dipilih

Mengecek kembali secara menyeluruh proses jawaban

Sumber: Adaptasi (Peter, 2012)

Maka penelitian ini dikategorikan sebagai penelitian deskriptif kualitatif karena penelitian ini dilakukan untuk memberikan uraian atas suatu keadaan tanpa adanya perlakuan khusus terhadap objek yang diteliti, dimana hasil penelitian diuraikan dengan data berupa kata-kata. Oleh karena itu, penelitian ini akan bermula dari penggalian data berupa pandangan dari informan dalam bentuk cerita rinci atau asli yang diungkapkan apa adanya sesuai dengan bahasa dan pandangan para subjek penelitian

Lokasi Penelitian di SD Aisyiyah Muhammadiyah 3. Waktu penelitian di bulan April dan mei pada tahun 2021. Subjek penelitian ini adalah 3 peserta didik kelas V SD Aisyiyah Muhammadiyah 3. Kriteria pemilihan subjek adalah peserta didik memiliki gaya belajar V-A-K (visual auditori dan kinestetik) yang lebih diatas. Focus penelitian ini kepada 1 peserta didik dengan cara belajar dari penglihatan, 1 peserta didik dengan cara belajar dari pendengaran, dan 1 peserta didik dengan cara belajar praktek yang semuanya adalah yang lebih diatas dari temantemannya.

Untuk memperoleh data yang diperlukan dalam penelitian ini, yang akan digunakan adalah: Obsevasi, Wawancara, Dokumentasi, dan Hasil tes peserta didik di Sekolah

Instrumen penelitian ini sebagai berikut: 1) peneliti, Sugiyono (2013) menjelaskan peneliti adalah instrumen kunci dalam penelitian kualitatif. Hal ini berfungsi dalam menentukan fokus penelitian, memilih subjek, melakukan pengumpulan data, menilai kualitas data, analisis data, menafsirkan data dan membuat simpulan dapat dilakukan dengan benar, 2) Tes Berpikir Kritis (TBK) yang terdiri dari 1 masalah berbentuk soal cerita, 3) Tes Gaya Belajar (TGB) yang diadaptasi peneliti dari instrumen gaya belajar oleh Chislett dan Chapman (2005) dengan menyesuaikan karakteristik berpikir dan bahasa pada siswa SD, dan 4) pedoman wawancara dibuat berdasarkan langkah-langkah berpikir kritis.

Untuk mengamati proses berpikir menurut Siswono (dalam Visitasari, 2013) dapat diamati melalui proses cara mengerjakan tes dan hasil yang ditulis secara terurut. Selain itu ditambah dengan wawancara mendalam mengenai cara kerjanya. Dengan demikian teknik pengumpulan data dalam penelitian ini untuk mengamati proses berpikir kritis siswa dalam memecahkan masalah berbentuk soal cerita dilakukan dengan cara pemberian TBK pada subjek, lalu dilakukan wawancara secara mendalam dengan menggunakan pedoman wawancara kepada subjek dari hasil pekerjaan TBK. Selain itu diperlukan observasi proses berpikir kritis siswa. Observasi yang dilakukan peneliti mengacu pada pendapat Arikunto (2006) bahwa observasi dapat dilakukan degan tes, kuesioner, rekaman gambar, atau rekaman suara. Dalam penelitian ini peneliti melakukan observasi dengan menggunakan handphone untuk merekam aktivitas dan hasil wawancara subjek, hal ini dilakukan agar setiap data hasil wawancara dan aktivitas subjek tidak terlewatkan.

Triangulasi yang digunakan adalah triangulasi teknik meliputi wawancara dan observasi hasil pekerjaan subjek pada tes berpikir kritis. Proses wawancara yang dilakukan adalah memberikan pertanyaan - pertanyaan kepada subjek terkait dengan soal cerita tes berpikir kritis yang diberikan, serta mengobservasi untuk menentukan perbedaan yang signifikan dari gaya belajar subjek penelitian yang diteliti.

Pengabsahan data merupakan salah satu faktor yang sangat penting dalam penelitian kualitatif, karena tanpa pengabsahan data yang diperoleh dari lapangan maka peneliti akan kesulitan dalam mempertanggung jawabkan hasil penelitiannya. Dalam hal ini pengabsahan data, 
peneliti menggunakan metode triangulasi teknik. Selanjutnya, Sugiyono (2013) menjelaskan, triangulasi Teknik berarti menggunakan pengumpulan data yang berbeda-beda untuk mendapatkan data dari sumber yang sama. Peneliti menggunakan observasi partisipatif, wawancara mendalam dan dokumentasi untuk sumber data yang sama secara serempak.

\section{HASIL DAN PEMBAHASAN}

\section{Deskripsi Karakteristik Objek Penelitian}

Dari keseluruhan siswa kelas V, yang menjadi subjek penelitian pada penelitian ini adalah siswa yang memiliki gaya belajar visual, auditori dan kinestetik tertinggi. Setelah memberikan tes gaya belajar kepada siswa kelas $\mathrm{V}$ maka dapat ditentukan siswa yang memiliki cara belajar tertinggi. Selanjutnya dipilih satu cara belajar visual auditori dan kinestetik. Dan dari hasil tes tersebut diperoleh tiga siswa yang mewakili masing-masing dari setiap gaya belajar mereka adalah Subjek 1, Subjek 2 dan Subjek 3 yang memiliki gaya belajar tertinggi berdasarkan gaya belajar mereka masing-masing.

Subjek 1 merupakan seorang siswi kelas V yang memiliki kecenderungan gaya belajar visual. Subjek 1 adalah nama samaran. Dari 13 siswa yang kecenderungan gaya belajarnya visual, Subjek 1 yang tertinggi. Maka Subjek 1 terpilih sebagai subjek pertama dalam penelitian ini.

Subjek 2 juga merupakan nama yang disamarkan. Dari 3 siswa yang memiliki kecenderungan gaya belajar auditori, Subjek 2 memiliki kecenderungan gaya belajar auditori tertinggi dibanding temannya. Maka Subjek 2 terpilih menjadi subjek kedua dalam penelitian ini.

Subjek 3 juga nama yang disamarkan untuk menjaga privasi subjek penelitian, 7 siswa yang memiliki kecenderungan gaya belajar kinestetik Subjek 3 memiliki hasil tes tertinggi setelah melalui tes gaya belajar yang diberikan oleh peneliti. Maka Subjek 3 lah yang menjadi subjek penelitian yang ketiga.

\section{Deskripsi Proses Berpikir Kritis}

a) Deskripsi Proses Berpikir Kritis Peserta Didik dalam Memecahkan Soal Cerita Matematika yang Memiliki Gaya Belajar Visual
De Porter dan Henacki (2000) mengemukakan bahwa gaya belajar visual (visual learner) menitik beratkan pada ketajaman penglihatan. Artinya, bukti - bukti konkret harus diperlihatkan terlebih dahulu agar peserta didik paham. Ciri - ciri peserta didik yang memiliki gaya belajar visual adalah kebutuhan yang tinggi untuk melihat dan menangkap informasi secara visual sebelum ia memahaminya.

Ciri - ciri seseorang yang memiliki gaya belajar visual diantaranya adalah sebagai berikut:

a. Rapi dan teratur

b. Berbicara dengan cepat

c. Perencanaan dan pengatur jangka panjang yang baik

d. Teliti terhadap detail

e. Mementingkan penampilan, baik dalam hal pakaian maupun presentasi

f. Pengeja yang baik dan dapat melihat kata kata yang sebenarnya dalam pikiran mereka

g. Mengingat apa yang dilihat dari pada yang didengar

h. Mengingat dengan asosiasi visual

i. Biasanya tidak tergantung oleh keributan

j. Mempunyai masalah untuk mengingat intruksi verbal kecuali jika ditulis, dan sering kali minta bantuan orang untuk mengulanginya

k. Pembaca cepat

1. Lebih suka membaca dari pada dibacakan

m. Membutuhkan pandangan dan tujuan yang menyeluruh serta bersikap waspada sebelum secara mental merasa pasti tentang suatu masalah atau proyek

n. Mencoret - coret tanpa arti selama berbicara di telefon dan dalam rapat

o. Lupa menyampaikan pesan verbal kepada orang lain

p. Sering menjawab pertanyaan dengan jawaban singkat ya atau tidak

q. Lebih suka melakukan demonstrasi dari pada berpidato

r. Lebih suka seni dari pada music

s. Seringkali mengetahui apa yang harus dikatakan, tetapi tidak pandai memilih kata kata 
t. Kadang - kadang kehilangan konsentrasi ketika mereka ingin memperhatikan

Subjek 1 subjek dengan gaya belajar visual, sebelum mengerjakan soal cerita kesan pertama yang terlihat dari Subjek 1 adalah penampilannya apa adanya tapi tetap terlihat rapi dibandingkan dengan temannya yang lain. Dan saat mengerjakan soal cerita Subjek 1 sibuk dengan dirinya sendiri karena focus terhadap soal yang diberikan. Mengulang-ulang membaca soal adalah caranya untuk memahami apa yang ditanyakan pada soal, sambil memikirkan persoalan dalam soal cerita. Pada akhirnya Subjek 1 termasuk cukup lama dalam menyelesaikan soal cerita.

b) Deskripsi Proses Berpikir Kritis Peserta Didik dalam Memecahkan Soal Cerita Matematika yang Memiliki Gaya Belajar Auditori

De Porter dan Henacki (2000) mengemukakan bahwa gaya belajar auditorial (auditory learners) adalah gaya belajar yang mengandalkan pada pendengaran untuk bisa memahami dan mengingatnya. Artinya, kita harus mendengarkan terlebih dahulu baru kemudian bisa mengingat dan memahami informasi yang diperoleh. Peserta didik yang mempunyaigaya belajar ini dapat belajar lebih cepat dengan berdiskusi dan mendengarkan apa yang guru katakan.

Ciri - ciri seseorang yang memiliki gaya belajar auditorial diantaranya adalah sebagai berikut:

1) Berbicara pada diri sendiri saat bekerja

2) Mudah terganggu oleh keributan

3) Menggerakkan bibir mereka dan mengucapkan tulisan di buku ketika membaca

4) Senang membaca dengan keras dan mendengarkan

5) Dapat mengulangi kembali dan menirukan nada, birama, dan warna suara

6) Merasa kesulitan untuk menulis, tetapi hebat dalam bercerita

7) Berbicara dalam irama yang terpola

8) Biasanya pembicara yang fasih

9) Lebih suka musik dari pada seni
10) Belajar dengan mendengarkan dan mengingat apa yang didiskusikan daripada yang dilihat

11) Suka berbicara, suka berdiskusi, dan menjelaskan sesuatu Panjang lebar

12) Mempunyai masalah dengan pekerjaan pekerjaan yang melibatkan visualisasi

13) Lebih pandai mengeja dengan keras dari pada menuliskannya

14) Lebih suka gurauan lisan dari pada membaca komik

Subjek 2 sebagai subjek gaya belajar auditori tertinggi. Sebelum mengerjakan soal cerita Subjek 2 memastikan temannya agar tidak rebut dalam kelas. Namun pada saat mengerjakan soal, Subjek 2 mengeja soal dengan keras dan suka berbicara dengan diri sendiri, mengakibatkan justru dia mengganggu tem annya yang sedang mengerjakan soal. Akhiranya diapun mengalami kesulitan untuk mengerjakan soal cerita, dan berimbas pada lamanya dia mengerjakan soal. Saat temannya selesai mengerjakan soal Subjek 2 belum selesai, walaupun pada akhirnya dapat menyelesaikannya.

\section{c) Deskripsi Proses Berpikir Kritis Peserta Didik dalam Memecahkan Soal Cerita Matematika yang Memiliki Gaya Belajar Kinestetik}

De Porter dan Henacki (2000) mengemukakan bahwa dalam gaya belajar kinestetik (tactual learners) ini kita harus menyentuh sesuatu yang memberikan informasi tertentu agar kita bisa mengingatnya. Gaya belajar ini merupakan aktivitas belajar dengan cara gerak, bekerja dan menyentuh. Peserta didik sulit untuk duduk diam berjam - jam karena keinginan mereka untuk beraktivitas dan eksplorasi sangatlah kuat.

Ciri - ciri seseorang yang memiliki gaya belajar kinestetik diantaranya adalah sebagai berikut:

1) Berbicara dengan perlahan

2) Menanggapi perhatian fisik

3) Menyentuh orang untuk mendapatkan perhatian mereka

4) Berdiri dekat ketika berbicara dengan orang

5) Selalu berorientasi pada fisik dan banyak bergerak 
6) Mempunyai perkembangan awal otot - otot yang besar

7) Belajar melalui manipulasi dan praktik

8) Menghafal dengan cara berjalan dan melihat

9) Menggunakan jari sebagai penunjuk ketika membaca

10) Banyak menggunakan isyarat tubuh

11) Tidak dapat duduk diam dalam waktu lama

12) Tidak dapat mengingat geografis, kecuali jika mereka memang telah pernah berada di tempat itu

13) Menggunakan kata - kata yang mengandung aksi

14) Menyukai buku - buku yang berorientasi pada plot mereka mencerminkan aksi dengan gerakan tubuh saat membaca

15) Kemungkinan tulisannya jelek

16) Ingin melakukan segala sesuatu

17) Menyukai permainan yang menyibukkan Subjek 3 merupakan subjek gaya belajar kinestetik tertinggi. Subjek 3 tidak dapat duduk diam dalam waktu lama, sehingga apa yang dia lakukan membuat temannya merasa terganggu. Itulah sebabnya Subjek 2 sebelum mengerjakan soal memastikan temannya agar tidak menganggu. Dan saat mengerjakan soalpun Subjek 3 pun tidak dapat diam, dia banyak menggunakan isyarat tubuh. Namun yang menjadi poin tambahan buat Subjek 3 adalah dapat dengan cepat menyelesaikan soal cerita, walaupun tulisannya agak sulit untuk dibaca.

Untuk memperoleh informasi pada tabel diatas peneliti melakukan wawancara mendalam kepada ketiga subjek. Proses wawancara dilakukan pada saat siswa sedang mengerjakan tes berpikir kritis dalam hal ini soal cerita matematika di kelas.

\section{Pembahasan}

Setelah melakukan serangkaian tes dan telah ditentukan subjeknya yang dilakukan pada hari kamis jam 10 pagi di SD Aisyiyah Muhammadiyah 3. Awalnya peneliti menginginkan agar tes gaya belajar diberikan langsung kepada siswa, tapi apalah daya kondisi yang tidak memungkinkan. Pandemik Covid 19 memaksa kita untuk melakukan segala hal dari rumah termasuk belajar dari rumah. Tentunya ini bertentangan dengan penelitian ini yang mengharuskan untuk datang ke sekolah karena yang menjadi penelitian dalam penelitian ini menuntut untuk melakukan pengamatan langsung ke semua siswa.

Solusi yang ditawarkan adalah dengan membuat tes gaya belajar melalui Google form. Dan akhirnya peneliti menyiapkan google form untuk memperoleh data. Google form adalah perangkat lunak administrasi survei yang disertakan sebagai bagian dari rangkaian penyunting google dokumen berbasis web gratis yang ditawarkan oleh google.

Namun setelah bertemu dengan Ibu Kepala sekolah, beliau menyarankan untuk tatap muka terbatas. Tatap muka terbatas maksudnya siswa dipanggil ke sekolah, namun hanya terbatas beberapaorang saja dan tentunya dengan tetap menjalankan protokol Kesehatan. Dan memang biasanya di kelas $\mathrm{V}$, khusus pelajaran matematika Ibu guru selalu mencoba mendatangkan siswa karena banyak hal yang mesti dijelaskan harus dengan tatap muka langsung. Mengapa penelitian dilakukan hari kamis karena pelajaran matematika jadwalnya adalah hari kamis. Jadi mengikut di roster pelajaran kelas $\mathrm{V}$ untuk mengantisipasi pertanyaan-pertanyaan orang tua siswa terkait kedatangan anaknya ke sekolah.

Jadi, yang datang ke sekolah hanya enam siswa, selebihnya siswa yang tidak dapat hadir diberikan kuesioner lewat google form diwaktu yang bersamaan. Begitupun saat diberikan tes berpikir kritis digunakan pola yang sama seperti yang dilakukan tes gaya belajar.

Tahapan menganalisis siswa berdasarkan gaya belajar untuk meyelesaikan persoalan matematika meliputi:

1. Pada langkah Identify, subjek menyebutkan pokok permasalahan, karena langsung mengerjakan soalnya;

2. Langkah Define, subjek menyebutkan apa yang diketahui dan ditanya dalam soal sambal membayangkan akuarium yang ada dirumahnya;

3. Langkah Enumerate; subjek menyebutkan bahwa harus mengetahui volume akuarium untuk menentukan volume air yang diisi; 
4. Langkah Analyze, subjek menjawab tepat volume air yang ingin diisi yakni separuhnya;

5. Langkah List, subjek memberikan alasan bahwa cara yang dilakukan adalah yang paling akurat;

6. Langkah Self-Correct, subjek mengecek kembali jawaban dengan cara mengecek jawaban dari awal sampai akhir (simpulan). meliputi:

Proses berpikir pada subjek auditori

a. Pada langkah Identify, subjek dapat menyebutkan fokus permasalahan,;

b. Langkah Define, subjek menyebutkan apa yang diketahui dan ditanya dalam soal namun sempat bertanya kembali untuk memastikan;

c. Langkah Enumerate; subjek menyebutkan untuk mencari jawaban volume air yang diisi, harus mengetahui luas akuarium;

d. Langkah Analyze, subjek dapat menganalisis cara dan jawaban yang dipilih.;

e. Langkah List, subjek memilih cara tersebut adalah karena car aitu satu satunya yang dia ketahui dan paling cepat;

f. Langkah Self-Correct, subjek mengecek kembali jawaban dengan cara mengecek jawaban akhir (simpulan) saja. meliputi:

Proses berpikir pada subjek kinestetik

1) Pada langkah Identify, subjek dapat menyebutkan fokus permasalahan;

2) Langkah Define, subjek menyebutkan apa yang diketahui dan ditanya dalam soal sambil mengerak gerakkan tangannya;

3) Langkah Enumerate; subjek menyebutkan untuk mencari jawaban volume air dapat dicari dengan mengetahui Panjang setiap sisi akuarium;

4) Langkah Analyze, subjek dapat menganalisis semua cara dan jawaban yang dipilih tepat;

5) Langkah List, subjek menyebutkan alasan yang tepat atas cara dan jawaban adalah yang paling mudah;

6) Langkah Self Correct, subjek mengecek kembali jawaban dengan cara memeriksa dari awal sampai akhir jawaban.
Berdasar uraian di atas tampak bahwa proses berpikir kritis subjek visual, kinestetik, dan auditori dalam memecahkan masalah berbentuk soal cerita secara umum memiliki kesamaan pada langkah, Identify, Enumerate Analyze, List, dan Self-Correct, sementara memiliki perbedaan Define. Perbedaannya terletak pada saat menjelaskan bentuk akuarium berdasarkan fakta dan alasan logis yang diberikan, perbedaan yang lain terletak pada ketelitian subjek dalam memeriksa kembali jawaban yang diperoleh. Subjek kinestetik dapat dikatakan memiliki proses berpikir kritis lebih baik dibandingkan subjek visual dan auditori pada Langkah Define. Sementara, subjek visual dapat dikatakan memiliki proses berpikir kritis lebih baik dibandingkan subjek auditori karena subjek sempat ragu dengan apa yang dia pahami tentang apa yang ditanyakan dalam soal.

Temuan lain yang didapat peneliti pada proses berpikir kritis siswa adalah ditemukan perbedaan proses gaya menjawab masalah pada langkah IDELAS (Identify, Define, Enumerate, Analyze, List, dan Self-Correct). Subjek visual cenderung melihat fokus permasahan dan menganalisa jawaban berdasarkan berusaha menggambarkan akuarium. Subjek auditori seringkali membaca soal dan jawaban agar dapat menyebutkan fokus permasalahan, apa yang diketahui, apa yang ditanyakan, dan menganalisa permasalahan. Sementara subjek kinestetik melakukannya dengan menggerak-gerakkan anggota badan dan pensil meski tidak menulis untuk menentukan fokus permasalahan. Hal ini mendukung pendapat DePorter \& Hernacki (2010) bahwa siswa seseorang visual mengingat dengan asosiasi visual, seseorang auditori berbicara kepada diri sendiri saat bekerja, dan seseorang kinestetik berorientasi pada fisik dan banyak bergerak.

Ada temuan menarik, bahwa subjek kinestetik saat mengerjakan soal cerita matematika yang paling cepat selesai. Hingga akhirnya membuat subjek yang lain terganggu karena subjek kinestetik tidak dapat dduk diam dalam waktu lama. Sehingga yang paling merasa terganggu adalah subjek auditori, karena mudah terganggu dengan keributan. Dengan demikian, harus ada solusi pembelajaran yang selama ini mengesampingkan proses berpikir kritis dan 
perbedaan gaya belajar. Maka hendaknya guruguru Sekolah Dasar khususnya guru kelas V SD Aisyiyah Muhammadiyah 3 menggunakan strategi, model, ataupun metode yang memperhatikan proses berpikir kritis dengan tidak menyamakan cara pengajaran atau pembelajaran bagi siswa yang memiliki gaya belajar visual, auditori, dan kinestetik agar siswa lebih kritis dalam memecahkan masalah soal cerita sesuai dengan gaya belajarnya masing-masing. Walaupun di kelas V lebih banyak subjek dengan gaya belajar visual dengan jumlah 13 orang, subjek dengan gaya belajar auditori hanya tiga orang dan subjek kinestetik tujuh orang. Tetap harus diperhatikan bahwa dalam kelas itu banyak keberagaman tentu salah satunya adalah gaya belajar.

Hasil proses berpikir kritis siswa berdasarkan gaya belajar dalam memecahkan masalah berbentuk soal cerita matematika berdasarkan langkah-langkah IDEALS dapat dilihat pada Tabel 2.

Tabel 2. Proses Berpikir Kritis Siswa Visual, Auditori, dan Kinestetik

\begin{tabular}{|c|c|c|c|}
\hline $\begin{array}{l}\text { Langkah - } \\
\text { Langkah } \\
\text { Berpikir } \\
\text { Kritis }\end{array}$ & Subjek Visual & Subjek Auditori & Subjek Kinestetik \\
\hline $\begin{array}{l}\text { Identify/ } \\
\text { Mengenali } \\
\text { Permasalahan }\end{array}$ & $\begin{array}{l}\text { Subjek menyebutkan pokok } \\
\text { permasalahan }\end{array}$ & $\begin{array}{l}\text { Subjek menyebutkan pokok } \\
\text { permasalahan, }\end{array}$ & $\begin{array}{l}\text { Subjek menyebutkan pokok } \\
\text { permasalahan }\end{array}$ \\
\hline $\begin{array}{l}\text { Definel } \\
\text { Memberi } \\
\text { Definisi }\end{array}$ & $\begin{array}{l}\text { - Subjek menyebutkan apa } \\
\text { yang diketahui dengan } \\
\text { membayangkan isi air dalam } \\
\text { akurium miliknya } \\
\text { - Subjek menyebutkan apa } \\
\text { yang ditanyakan dengan } \\
\text { membayangkan akuarium } \\
\text { yang ada di rumahnya }\end{array}$ & $\begin{array}{l}\text { - Subjek menyebutkan apa } \\
\text { yang diketahui yakni } \\
\text { akuarium yang berbentuk } \\
\text { kubus namun sempat } \\
\text { bertanya kembali untuk } \\
\text { memastikan } \\
\text { - Subjek menyebutkan apa } \\
\text { yang ditanyakan berupa } \\
\text { volume air yang } \\
\text { dimasukkan }\end{array}$ & $\begin{array}{l}\text { - Subjek menyebutkan apa } \\
\text { yang diketahui yakni } \\
\text { akuarium yang berbentuk } \\
\text { kubus sambil menggerakkan } \\
\text { tangannya } \\
\text { - Subjek menyebutkan apa } \\
\text { yang ditanyakan berupa } \\
\text { volume air yang dimasukkan }\end{array}$ \\
\hline $\begin{array}{l}\text { Enumeratel } \\
\text { Menyebutkan } \\
\text { pilihan-pilihan }\end{array}$ & $\begin{array}{l}\text { Subjek menyebutkan bahwa } \\
\text { harus mngetahui volume } \\
\text { akuarium untuk menentukan } \\
\text { volume air yang akan diisi }\end{array}$ & $\begin{array}{l}\text { Subjek menyebutkan untuk } \\
\text { mencari jawaban volume air } \\
\text { yang diisi, harus mengetahui } \\
\text { luas akuarium }\end{array}$ & $\begin{array}{l}\text { Subjek menyebutkan untuk } \\
\text { mencari jawaban volume air } \\
\text { dapat dicari dengan mengetahui } \\
\text { panjang setiap sisi akuarium }\end{array}$ \\
\hline $\begin{array}{l}\text { Analyzel } \\
\text { Menganalisa }\end{array}$ & $\begin{array}{l}\text { Subjek menjawab tepat volume } \\
\text { air yang ingin diisi yakni } \\
\text { separuhnya }\end{array}$ & $\begin{array}{l}\text { Subjek menjawab dengan } \\
\text { tepat }\end{array}$ & $\begin{array}{l}\text { Subjek menjawab dengan tepat } \\
\text { volume air dalam akuarium }\end{array}$ \\
\hline $\begin{array}{l}\text { List/ } \\
\text { Menyebutkan } \\
\text { Alasan } \\
\text { Pemilihan }\end{array}$ & $\begin{array}{l}\text { Alasan memilih cara tersebut } \\
\text { yakni cara tersebut paling akurat }\end{array}$ & $\begin{array}{l}\text { Alasan subjek memilih cara } \\
\text { tersebut adalah karena itu } \\
\text { cara satu satunya yang dia } \\
\text { ketahui dan paling cepat }\end{array}$ & $\begin{array}{l}\text { Alasannya karena cara tersebut } \\
\text { paling mudah }\end{array}$ \\
\hline $\begin{array}{l}\text { Self-Correct/ } \\
\text { Mengecek } \\
\text { Kembali }\end{array}$ & $\begin{array}{l}\text { Subjek mengecek kembali } \\
\text { proses jawaban dengan cara } \\
\text { membaca jawaban dari awal } \\
\text { sampai simpulan jawabannya }\end{array}$ & $\begin{array}{l}\text { Subjek mengecek kembali } \\
\text { proses cara dan jawaban } \\
\text { yang digunakan dengan } \\
\text { mengoreksi jawaban akhir } \\
\text { saja }\end{array}$ & $\begin{array}{l}\text { Subjek mengecek Kembali dari } \\
\text { awal sampai akhir simpulan } \\
\text { jawaban }\end{array}$ \\
\hline
\end{tabular}


Subjek 1 subjek dengan gaya belajar visual, sebelum mengerjakan soal cerita kesan pertama yang terlihat dari Subjek 1 adalah penampilannya apa adanya tapi tetap terlihat rapi dibandingkan dengan temannya yang lain. Dan proses berpikir kritis siswa visual seperti saat mengerjakan soal cerita Subjek 1 sibuk dengan dirinya sendiri karena focus terhadap soal yang diberikan. Mengulang-ulang membaca soal adalah caranya untuk memahami apa yang ditanyakan pada soal, sambil memikirkan persoalan dalam soal cerita. Pada akhirnya Subjek 1 termasuk cukup lama dalam menyelesaikan soal cerita.

Subjek 2 sebagai subjek gaya belajar auditori tertinggi. Sebelum mengerjakan soal cerita Subjek 2 memastikan temannya agar tidak rebut dalam kelas. Proses berpikir kritis siswa Auditori seperti pasada saat mengerjakan soal, Subjek 2 mengeja soal dengan keras dan suka berbicara dengan diri sendiri, mengakibatkan justru dia mengganggu tem annya yang sedang mengerjakan soal. Akhiranya diapun mengalami kesulitan untuk mengerjakan soal cerita, dan berimbas pada lamanya dia mengerjakan soal. Saat temannya selesai mengerjakan soal Subjek 2 belum selesai, walaupun pada akhirnya dapat menyelesaikannya.

Subjek 3 merupakan subjek gaya belajar kinestetik tertinggi. Subjek 3 tidak dapat duduk diam dalam waktu lama, sehingga apa yang dia lakukan membuat temannya merasa terganggu. Itulah sebabnya Subjek 2 sebelum mengerjakan soal memastikan temannya agar tidak menganggu. Proses berpikir kritis siswa kinestetik seperti saat mengerjakan soalpun Subjek 3 tidak dapat diam, dia banyak menggunakan isyarat tubuh. Namun yang menjadi poin tambahan buat Subjek 3 adalah dapat dengan cepat menyelesaikan soal cerita, walaupun tulisannya agak sulit untuk dibaca.

Berdasarkan simpulan penelitian, saran yang dapat diberikan peneliti adalah hendaknya guru lebih memperhatikan proses berpikir kritis siswa dalam memecahkan masalah khususnya masalah berbentuk soal cerita saat pembelajaran berdasarkan perbedaan gaya belajar visual, auditori, kinestetik siswa karena masing-masing siswa yang memiliki perbedaan gaya belajar pasti memiliki karakteristik proses berpikir yang berbeda pula. Oleh karena itu siswa hendaknya diperhatikan proses berpikir kritisnya dan pembelajaran yang dilakukan berorintasi pada pemecahan masalah agar siswa terbiasa memecahkan masalah, sehingga diharapkan proses berpikir kritis siswa semakin baik dan meningkat. Dibutuhkan pula pemetaan cara belajar bagi siswa yang memiliki gaya belajar berbeda (Visual, Auditori, dan Kinestetik), misalnya siswa dengan gaya belajar visual dilatih pemecahan masalah dengan menyajikan masalah soal cerita berbentuk gambar-gambar, siswa auditori lebih sering diajak diskusi agar terbentuk pembelajaran interaktif secara lisan, dan siswa kinestetik tidak dibatasi ruang geraknya dalam memecahkan masalah.

\section{SIMPULAN DAN REKOMENDASI}

Subjek 1 subjek dengan gaya belajar visual, sebelum mengerjakan soal cerita kesan pertama yang terlihat dari Subjek 1 adalah penampilannya apa adanya tapi tetap terlihat rapi dibandingkan dengan temannya yang lain. Dan proses berpikir kritis siswa visual seperti saat mengerjakan soal cerita Subjek 1 sibuk dengan dirinya sendiri karena focus terhadap soal yang diberikan. Mengulang-ulang membaca soal adalah caranya untuk memahami apa yang ditanyakan pada soal, sambil memikirkan persoalan dalam soal cerita. Pada akhirnya Subjek 1 termasuk cukup lama dalam menyelesaikan soal cerita.

Subjek 2 sebagai subjek gaya belajar auditori tertinggi. Sebelum mengerjakan soal cerita Subjek 2 memastikan temannya agar tidak rebut dalam kelas. Proses berpikir kritis siswa Auditori seperti pasada saat mengerjakan soal, Subjek 2 mengeja soal dengan keras dan suka berbicara dengan diri sendiri, mengakibatkan justru dia mengganggu tem annya yang sedang mengerjakan soal. Akhiranya diapun mengalami kesulitan untuk mengerjakan soal cerita, dan berimbas pada lamanya dia mengerjakan soal. Saat temannya selesai mengerjakan soal Subjek 2 belum selesai, walaupun pada akhirnya dapat menyelesaikannya.

Subjek 3 merupakan subjek gaya belajar kinestetik tertinggi. Subjek 3 tidak dapat duduk diam dalam waktu lama, sehingga apa yang dia lakukan membuat temannya merasa terganggu. Itulah sebabnya Subjek 2 sebelum mengerjakan soal memastikan temannya agar tidak menganggu. 
Proses berpikir kritis siswa kinestetik seperti saat mengerjakan soalpun Subjek 3 tidak dapat diam, dia banyak menggunakan isyarat tubuh. Namun yang menjadi poin tambahan buat Subjek 3 adalah dapat dengan cepat menyelesaikan soal cerita, walaupun tulisannya agak sulit untuk dibaca.

Berdasarkan simpulan penelitian, saran yang dapat diberikan peneliti adalah hendaknya guru lebih memperhatikan proses berpikir kritis siswa dalam memecahkan masalah khususnya masalah berbentuk soal cerita saat pembelajaran berdasarkan perbedaan gaya belajar visual, auditori, kinestetik siswa karena masing-masing siswa yang memiliki perbedaan gaya belajar pasti memiliki karakteristik proses berpikir yang berbeda pula. Oleh karena itu siswa hendaknya diperhatikan proses berpikir kritisnya dan pembelajaran yang dilakukan berorintasi pada pemecahan masalah agar siswa terbiasa memecahkan masalah, sehingga diharapkan proses berpikir kritis siswa semakin baik dan meningkat. Dibutuhkan pula pemetaan cara belajar bagi siswa yang memiliki gaya belajar berbeda (Visual, Auditori, dan Kinestetik), misalnya siswa dengan gaya belajar visual dilatih pemecahan masalah dengan menyajikan masalah soal cerita berbentuk gambar-gambar, siswa auditori lebih sering diajak diskusi agar terbentuk pembelajaran interaktif secara lisan, dan siswa kinestetik tidak dibatasi ruang geraknya dalam memecahkan masalah.

\section{DAFTAR PUSTAKA}

Amina, S. R. (2016). Analisis Aktivitas Belajar Siswa Berdsarkan Gaya Belajar Visual Auditori Kinestetik Siswa Pada Pembelajaran Biologi Kelas XI IPA MAN 1 Medan. Jurnal Pelita Pendidikan, 5(4), 355-360.

Amir, M. F. (2015). Proses Berpikir Kritis Siswa Sekolah Dasar Dalam Memecahkan. Journal Math Educator Nusantara, 01, 159-170.

Asmad. (2017). Penerapan Pendekatan Inkuiri Untuk Meningkatkan Matematika. Pedagogi Jurnal Penelitian Pendidikan, 04(01), 40-50.

Hayyu, M. N., \& Budhi, W. (2016). Hubungan Antara Pola Asuh Orang Tua, Lingkungan,
Dan Gaya Belajar Dengan Prestasi Belajar Fisika. Jurnal Ilmiah Pendidikan FisikaCOMPTON, 3(1), 9-22.

Hidayah, S. R., Trapsilasiwi, D., Setiawani, S., \& Matematika. (2016). Proses Berpikir Kritis Siswa Kelas VII F Mts . Al-Qodiri 1 Jember dalam Pemecahan Masalah Matematika Pokok Bahasan Segitiga dan Segi Empat ditinjau dari Adversity Quotient ( The Process o f Critical Thinking Students Class VII F Mts . AlQodiri 1 Jember i. Jurnal Edukasi UNEJ, 3(3), 21-26.

Nitya, I. G. E. P. D., Koyan, I. W., \& Partadjaja, T. R. (2013). Penerapan Model Polya Untuk Meningkatkan Aktivitas Dan Hasil Belajar Matematika Dalam Menyelesaikan Soal Cerita Pada Siswa Kelas V SD No . 2 Pemaron. Mimbar PGSD, 1(2).

Putri, A. W. (2013). Pengaruh Gaya Belajar Siswa ( Visual , Auditorial Dan Kinestetik) Pada Mata.

Ramalisa, Y. (2013). Proses Berpikir Kritis Siswa Sma Tipe Kepribadian Thinking Dalammemecahkan Masalahmatematika. Edumatica, 03(01), 42-47.

Rohati. (2014). Proses Berpikir Kritis Siswa Smp Tipe Influence Dalam Memecahkan Masalah Matematika. Edumatica, 04(01), 44-50.

Rokhman, A. M., \& Basuki, I. (2013). ( Audiotory Learning Dan Visual Learning ) Terhadap Hasil Belajar. Jurnal Penelitian Pendidikan Elektro, 01(1), 115-121.

Sari, A. K. (2014). Analisis Karakteristik Gaya Belajar VAK (Visual, Auditorial, Kinestetik) Mahasiswa Pendidikan. Jurnal Ilmiah Edutic, 1(1), 1-12.

Sumarwati. (2008). Soal Cerita Dengan Bahasa Komunikatif Untuk Meningkatkan Kualitas Pembelajaran Matematika Sekolah Dasar. Jurnal Ilmu Pendidikan, 19(1), 26-36.

Visitasari, R., Yuli, T., Siswono, E., Matematika, J., \& Surabaya, U. N. (2013). Kemampuan Siswa Memecahkan Masalah Berbentuk Soal Cerita Aljabar Menggunakan Tahapan Analisis Newman. 
Jurnal PAJAR (Pendidikan dan Pengajaran)

Volume 5 Nomor 6 November | ISSN Cetak : 2580 - 8435| ISSN Online : 2614 - 1337

DOI : http://dx.doi.org/10.33578/pjr.v5i6.8502

Wahyuni, Y. (2017). Identifikasi Gaya Belajar ( Visual, Auditorial, Kinestetik).

Universitas Bung Hatta. JPPM, 10(2), $128-132$.

Wahyuningtyas, W. (2013). Peningkatan Kemampuan Pemecahan Masalah Matematika Siswa Pada Materi Turunan

Fungsi Melalui Diskusi Kelompok. MATHEducation, $0 x(\mathrm{xx}), 1-8$. 